\title{
PENGARUH PENGGUNAAN MEDIA PEMBELAJARAN ALAT PERMAINAN EDUKATIF ( APE ) TERHADAP PENINGKATAN PERKEMBANGAN KOGNITIF ANAK IN PAUD TUNAS BANGSA PODOMORO PRINGSEWU
}

\author{
Nada Sholiha Romadhona, Ruly Nadian Sari \\ Jurusan Pendidikan Guru Madrasah Ibtidai’yah \\ Intitusi : STIT PRINGSEWU - LAMPUNG \\ Alamat : Jalan Raya Wonokriyo Gadingrejo Pringsewu 35373, Telp. 0729-333091 \\ website : www.stitpringsewu.ac.id \\ e-mail: nadasholiha88@gmail.com, rulynadiansari@gmail.com
}

\begin{abstract}
Abstrack
The problem of this research is the development of cognitive development in children. This study aims to determine the effect of the use of instructional media on educational learning tools to improve children's cognitive development. This research is a quantitave. The population of this study is a group of aids buds of podomoro nation pringsewu sub-district, preweew district, amounting to forty one children and the sample was forty one children. Data collection techniques use observase and questionnaries. Data were analysed using regression tests. The results of this study showed an increase in children's cognitive development with learning media educational game tools with $\mathrm{t}$ arithmetic $=10,405$ with a significant value of $0,682>0,05$, then $\mathrm{h} 0$ is accepted which means there is a significant effect of the variable then on the participant variable of $68,2 \%$.
\end{abstract}

Keyword : Cognitive development, learning media

\begin{abstract}
Abstrak
Masalah dalam penelitian ini adalah belum berkembangnya perkembangan kognitif anak. Penelitian ini bertujuan untuk mengetahui pengaruh penggunaan media pembelajaran alat permainan edukatif APE terhadap peningkatan perkembangan kognitif anak usia dini . Penelitian ini merupakan penelitian kuantitatif. Populasi penelitian ini adalah kelompok A PAUD Tunas Bangsa Podomoro Kecamatan Pringsewu Kabupaten Pringsewu berjumlah 41 anak dan sampelnya berjumlah 41 anak. Teknik pengumpulan data menggunakan observasi dan kuesioner. Data dianalisis dengan menggunakan uji regeranssion. Hasil penelitian ini menunjukkan peningkatan perkembangan kognitif anak dengan media pembelajaran alat permainan edukatif APE dengan di ketahui nilai Thitung $=10,405$ dengan nilai signifikan 0,682 >0,05, maka Ho ditolak dan $\mathrm{H} 1$ diterima yang berarti ada pengaruhnya yang nyata ( signifikan ) variable trust $(\mathrm{x})$ terhadap variable partisipan ( Y ) sebesar 68,2\%.
\end{abstract}

Kata Kunci : Perkembangan Kognitif , Media APE 


\section{A. PENDAhuluan}

\section{Anak Usia Dini menurut NAEYC}

(National Association Educational Young

Children) merupakan sosok individu yang sedang menjalani suatu proses perkembangan dengan pesat dan fundamental bagi kehidupan selanjutnya, berada pada rentang usia 0-8 tahun. Sedangkan anak usia dini disarikan menurut Undang-undang Nomor 20 tahun 2003 tentang Sistem Pendidikan Nasional disebutkan bahwa mereka adalah anak yang berada pada rentang usia sejak lahir sampai dengan enam tahun. Dan jika disesuaikan dengan pendapat internasional, maka anak usia dini di Indonesia adalah mereka yang sejak lahir ( usia 0 tahun) hingga memasuki jenjang SD awal. Namun beberapa hasil penelitian menunjukkan bahwa sejak masa konsepsi (dalam kandungan), janin telah berkembang dan terbukti telah dapat dilakukan stimulasi yang dapat mengembangkan berbagai kepekaan dan kemampuan dasarnya. Sebagaimana kita ketahui bersama, dunia anak adalah dunia bermain. Oleh karena itu, selama rentang perkembangan usia dini anak melakukan kegiatan dengan bermain, mulai dar bayi ,balita hingga masa kanak-kanak.Dengan bermain anak dapat menyalurkan kelebihan energi yang terkandung dalam tubuhnya sekaligus belajar atau berlatih dalam suasana riang untuk meningkatkan fungsi-fungsi fisik maupun psikisnya.

Pada usia 3-4 tahun, organ-organ tubuh anak sudah mengalami kemajuan yang sangat pesat. Organ-organ tubuh sudah berkembang secara sempurna dan memiliki proposi yang seimbang. Kemampuan psikomotorik anak semakin baik. Anak dapat meloncat, memanjat, merangkak, di bawah meja dan kursi, serta dapat melakukan gerakan-gerakan yang kasar dan halus dengan tangan ,kaki dan jari-jarinya. Tangan dan mata sudah mampu bekerja sama dalam koordinasi yang baik,anak lebih dapat mengadakan orientasi dalam situasi-situasi yang tidak asing. Pada usia ini,tangan anak merupakan alat untuk mengadakan eksplorasi keliling, yaitu melalui manipulasi dengan benda-benda ,terutama alat-alat permainan dan benda-benda di lingkungannya.(Erni Sukmawati Dewi 2009:1).

Pendidikan anak usia dini ( early child education) sangat penting dilaksanakan sebagai dasar pembentukan karakter ,budi pekerti, cerdas ,ceria, terampil dan bertaqwa kepada Tuhan Yang Maha Esa. Pendidikan anak usia dini tidak harus selalu mengeluarkan biaya yang mahal atau melalaui suatu wadah tertentu, melainkan anak usia dini dapat dimulai drumah atau dalam keluarga dalam ( Permen No 58 tahun 2009).

Anak usia dini adalah sosok individu yang unik , mereka dilahirkan membawa kemampuan, potensinya masing-masing serta bakat dan minat yang berbeda. Masing-masing anak dalam mempunyai bakat,kemampuan sangatlah berbedabeda dalam karakteristik perkembangan kognitif anak.

Perkembangan yaitu sebuah proses perubahan tentang pola-pola dalam rentang kehidupan manusia . Perkembangan bersifat sistematis artinya perkembangan bersifat berkesinambungan dan terorganisir. Perkembangan harus distimulasi dari sejak dini agar perkembangan selanjutnya akan berkembang untuk masa selanjutnya akan berkembang secara optimal. Menurut Piaget, pada usia 3-6 tahun anak berada pada masa praoperasional. Pada masa ini anak sudah dapat berfikir dalam simbol namun belum dapat menggunakan logika. Berfikir dalam simbol anak sudah bisa menggambarkan berbagai hal dalam pemikiran nya tanpa kehadiran benda tersebut. Misal seorang anak menginginkan es krim. Tanpa harus melihat es krim, ia sudah dapat menggamb arkan bentuk es krim sampai pada rasanya.

Salah satu perkembangan yang akan dikembangkan untuk mendidik anak usia dini adalah perkembangan kognitif anak. Anak-anak dapat belajar melalui interaksi antara guru dan anak guna melihat kemampuan daya ingat anak dalam berpengalaman dalam belajar. Kognitif sering diartikan sebagai proses berfikir atau sebuah kecerdasan yang dimiliki oleh manusia. Perkembangan kognitif memberikan batasan dimana kemampuan,kecerdasan, dan hubungan anak didik merupakan proses membentuk struktur yang diperlukan dalam interaksi terus menerus dengan lingkungan nya.

Faktor kognitif mempunyai peranan penting bagi keberhasilan anak dalam belajar karena sebagian besar aktivitas dalam belajar selalu berhubungan dengan masalah mengingat dan berfikir. Masalah dimana anak bosen dalam belajar atau bermain. Teori perkembangan tersebut diwakili konstruktivisme, yang memandang perkembangan kognitif sebagai suatu proses dimana anal secara aktif membangun sistem makna dan pemahaman realitas melalui pengalaman-pengalaman dan interaksi mereka. Teori Piaget mengasumsikan bahwa seluruh siswa tumbuh melewati urutan perkembangan kognitif yang sama, namun pertumbuhan itu berlangsung pada kecepatan dan keaktifan anak dalam belajar menggunakan media pembelajaran alat permainan edukatif ( APE ). Berdasarkan peraturan mentri pendidikan dan kebudayaan republik indonesia no. 137 tahun 2014 tentang standar nasional pendidikan anak usia dini bahwa perkembanagan kognitif anak terdapat tiga sub tahap yaitu belajar dan pemecah masalah, berfikir logis,serta berfikir semua simbolik. Peneliti ini akan lebih membahas tentang perkembangan kognitif anak. 
menggunakan media pembelajaran alat permainan edukatif ( APE )

Pengertian alat permainan edukatif ( APE) adalah semua alat yang digunakan anak untuk memenuhi naluri bermainnya. Alat permainan edukatif untuk pendidikan anak usia dini adalah alat yang sengaja dirancang untuk meningkatkan aspek perkembangan anak. Dengan bermain anak dapat melakukan kegiatan yang merangsang dan mendorong pengembangan aspek-aspek kemampuan dan potensi yang telah dimiliki anak. Dalam melakukan aktivitas bermain, anak tentunya membutuhkan berbagai alat permainan yang mengundang unsur nilai edukatif. Alat permainan edukatif ( APE ) sangat penting di berikan kepada anak terutama anak usia dini di paud tunas bangsa podomoro pringsewu. Selain bertujuan untuk agar anak tidak memiliki rasa bosan atau jenuh dalam belajar, APE juga akan membuat anak menjadi bertambah senang dan aktif dalam bereksplorasi dengan pembelajaran sesuai tema.

Untuk dapat melihat dan memahami secara lebih mendalam mengenai apakah suatu permainan dapat dikatagorikan sebagai alat permainan edukatif untuk anak usia dini atau tidak, terdapat beberapa ciri yang harus dipenuhinya yaitu : alat permainan tersebut ditunjukan untuk anak usia dini , difungsikan untuk mengembangkan dengan berbagai perkembangan anak usia dini, dapat diguakan dengan berbagai cara,bentuk,macam tujuan aspek pengembangan atau bermanfaat multiguna,aman atau tidak berbahaya bagi anak. Adapun manfaat alat perminan edukatif anak usia dini adalah mengaktifkan alat indra secara komunikatif dan dapat ditingkatkan dengan daya serap dan membangkitkan minat belajar sehingga mendorong anak untuk memainkan nya. Syarat dalam menggunakan alat permainan edukatif ( APE ) yaitu : mudah yang arinya mudah dalam membuatnya, aman yang artinya tidak membahayakan anak, murah yang artinya pengadaan biaya, asyik yang artinya nyaman di gunakan untuk anak. Berdasarkan penelitian di PAUD Tunas Bangsa ada 2 bagian APE yaitu APE di dalam dan di luar. Pada APE di dalam ada beberapa alat permainan edukatif yang akan meningkatkan kecerdasan kognitif anak diantaranya puzzle, balok, buku bergambar, buku cerita, tape, majalah, krayon, dan boneka. Pada APE di luar ada 4 alat permaian yaitu bola dunia,jungkat jungkit, seluncuran , ayunan. Dengan semua APE yang sudah ada di Paud Tunas Bangsa bisa membuat anak lebih aktif dan kreatif pada saat pembelajaran. Saat ini kondisi media pembelajaran alat permainan edukatif ( APE ) masih bagus dan komplit ,bahkan anak-anak lebih suka bermain menggunakan alat permaian edukatif di luar .

Berdasarkan hasil observasi di bawah ini perkembangan kognitif anak di tunjukkan dengan anak malas bertanya dan ribut. Pada teori taksonomi bloom mengidentifikasikan skill mulai dari tingkat tinggi yang rendah hingga yang tinggi. Tentunya untuk mencapai tujuan yang lebih tinggi, level yang rendah harus dipenuhi lebih dahulu. Dalam kerangka konsep ini tujuan pendidikan ini oleh bloom di bagi menjadi tiga domain/ ranah kemampuan intelektual ( intellectual behavions ) yaitu kognitif,afektif, dan psikomotorik. Dalam ranah kognitif itu terdapat enam jenjang proses berfikir, mulai dari jenjang terendah sampai dengan jenjang yang tertinggi yang meliputi : pengetahuan ( knowldge) CI , pemahaman ( comprehension ) C2, penerapan ( application) C3, analisa ( analysis ) C4, sintesis ( synthesis) C5, Evaluasi ( evaluation ) C6. Dalam menggunakan teori blomm peneliti mengambil beberapa indikator perkembangan kogitif yang sudah tertera pada tabel sebagai berikut:

Tabel hasil observasi anak

( Indikator perkembangan kognitif )

\begin{tabular}{|l|l|l|l|l|l|}
\hline NO & Indikator & Ya & Tidak & Keterangan & Presentase \\
\hline 1. & $\begin{array}{l}\text { Mengenal } \\
\text { warna }\end{array}$ & $\sqrt{ }$ & & Sudah bisa & $75 \%$ \\
\hline 2. & $\begin{array}{l}\text { Mengenal } \\
\text { bentuk }\end{array}$ & $\sqrt{ }$ & & Sudah bisa & $80 \%$ \\
\hline 3. & $\begin{array}{l}\text { Mengenal } \\
\text { gambar }\end{array}$ & $\sqrt{ }$ & & Sudah bisa & $77 \%$ \\
\hline 4. & $\begin{array}{l}\text { Mengenal } \\
\text { angka }\end{array}$ & $\sqrt{ }$ & & Sudah bisa & $55 \%$ \\
\hline 5. & $\begin{array}{l}\text { Mengenal } \\
\text { huruf }\end{array}$ & $\sqrt{ }$ & & Sudah bisa & $47 \%$ \\
\hline
\end{tabular}

Sumber : hasil observasi awal

Dari tabel diatas dapat diketahui bahwa perkembangan kognitif anak di PAUD Tunas Bangsa Podomoro sudah berkembang cukup baik.

Berdasarkan uraian di atas, penelitian, merasa perlu melakukan upaya dalam meningkatkan perkembangan kognitif anak dengan memberikan aktivitas belajar dengan media pembelajaran alat Permainan edukatif (APE). Aktivitas dengan media APE ini dapat mempengaruhi kecerdasan kognitif pada anak. Maka peneliti merasa bahwa peneliti ini perlu diteliti lebih dalam untuk merumuskan dan memecahan masalah di sekolah Paud Tunas Bangsa Podomoro.

\section{B. TUJUAN}

Tujuan dari peneliti ini adalah untuk mengetahui pengaruh media pembelajaran alat 
permainan edukatif ( APE ) terhadap peningkatan perkembangan kognitif anak usia dini di Paud Tunas Bangsa Podomoro Kecamatan Pringsewu Kabupaten Pringsewu .

\section{METODE PENELITIAN}

Metode penelitian adalah cara atau teknik utama yang digunakan dalam melakukansuatu penelitian dengan melalui metode-metode ilmiah. Penelitian ini menggunakan penelitian kuantitatif. Penelitian kuantitatif adalah suatu cara pengolah data yang dilakukan dengan jalan menyusun secara sistematis dalam bentuk angka-angka dan presentase mengenai objek yang diteliti, sehingga diperoleh kesimpulan umum (Agung,2012). Populasi peneliti ini adalah anak kelompok A di Paud Tunas Bangsa Podomoro Kecamatan Pringsewu Kabupaten Pringsewu yang berjumlah 41 anak dan sampel penelitian berjumlah 41 anak. Objek yang ditangani dalam penelitian ini adalah peningkatan perkembangan kognitif anak usia dini dalam menggunakan media pembelajaran alat permainan edukatif ( APE ) kelompok A yang berjumlah 41 anak. Dalam peneliti ini menggunakan 2 variabel yaitu : variable bebas media pembelajaan alat permainan edukatif (APE), variabel terikat peningkatan perkembangan kognitif. Untuk mengumpulkan data tentang penggunan media pembelajaran APE terhadap peningkatan perkembangan kognitif anak digunakan uji regression pada SPSS. Teknik pengumpulan data menggunakan observasi.

\section{HASIL DAN PEMBAHSAN}

Hasil peneliti ini menunjukkan bahwa dengan penggunaan media pembelajaran alat permainan edukatif (APE) dan peningkatan perkembangan kognitif anak pada kelompok A di Paud Tunas Bangsa Podomoro Kecamatan Pringsewu Kabupaten Pringsewu. Peneliti akan menyajikan dan hasil objek peneliti perangkat yang telah di tentukan yaitu analisis deskriptif kuantitatif. Penentuan sampel dilakukan dengan menggunakan kuesioner ( angket) sehingga jumlah responden dalam penelitian adalah 41 .

Berdasarkan hasil analisi uji regression diketahui bahwa membandingkan nilai $\mathrm{t}$ hitung dan t table sebagai berikut:

1. Jika nilai $\mathrm{t}$ hitung $>$ dari $\mathrm{t}$ table artinya variable bebas berpengaruh terhadap variable terikat

2. Jika nilai $\mathrm{t}$ hitung < dari nilai t table yaitu artinya variable bebas tidak perpengaruh terhadap variable terikat.

Dalam hal ini peneliti sudah mencoba uji regression yang sudah output data ke dalam SPSS beserta penjelasan nya.
Tabel 1. Model Summary

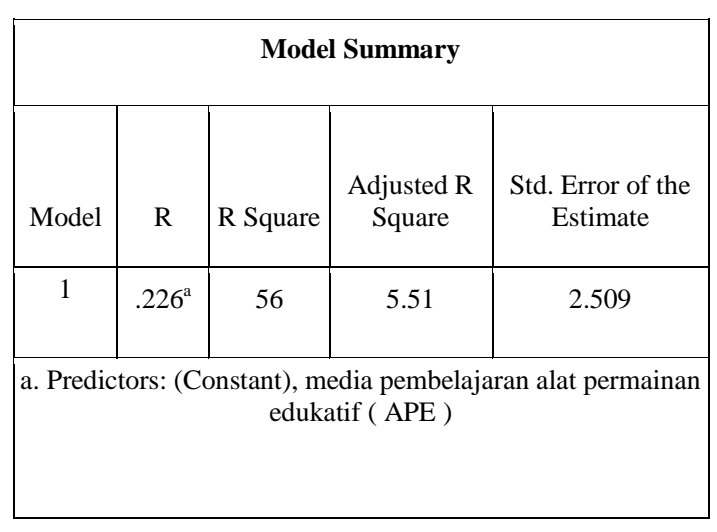

Output bagian ( Model Summary ) table diatas dapat dijelaskan besarnya nilai korelasi / hubungan (R) yaitu sebesar 0,226 dan dijelaskan besarnya presentase pengaruh variable bebas terhadap variable terikat yang disebut koefisien determinasi yang merupakan hasil dari penguadratan R. Dari output tersebut diperoleh koefisien determinasi ( R2) sebesar 0,56 yang mengandung pengertian bahwa pengaruh variable bebas ( Trust ) terhadap variable terikat (partisipasi) adalah 56\%. Sedangkan sisanya dipengaruhi oleh variable yang lainnya.

Tabel 2. ANOVA

\begin{tabular}{|c|c|c|c|c|c|}
\hline \multicolumn{6}{|c|}{ ANOVA $^{b}$} \\
\hline Model & $\begin{array}{l}\text { Sum of } \\
\text { Squares }\end{array}$ & $d f$ & $\begin{array}{l}\text { Mean } \\
\text { Square }\end{array}$ & $\mathrm{F}$ & Sig. \\
\hline Regressio & 5.099 & 1 & 5.099 & .810 & $.682^{\mathrm{a}}$ \\
\hline Residual & 94.430 & 15 & 6.295 & & \\
\hline Total & 99.529 & 16 & & & \\
\hline \multicolumn{6}{|c|}{$\begin{array}{l}\text { a. Predictors: (Constant), media pembelajaran alat permainan edukatif } \\
\text { ( APE ) }\end{array}$} \\
\hline \multicolumn{5}{|c|}{$\begin{array}{l}\text { b. Dependent Variable: peningkatan perkembangan } \\
\text { kognitif anak usia dini }\end{array}$} & \\
\hline
\end{tabular}

Output bagian ketiga ( ANOVA ) pada bagian ini untuk menjelaskan apakah pengaruh yang nyata ( signifikan) variable trust ( $\mathrm{X}$ ) terhadap variable partisipan ( $\mathrm{Y}$ ). Dari output tersebut terlihat bahwa Fhitung $=0,810$ dengan tingkat signifikan / Probabilitas $0,682>0,05$, maka model regresi dapat dipakai untuk memprediksi variable partisipasi. 
Tabel 3. Coefficients

\begin{tabular}{|c|c|c|c|c|c|c|}
\hline \multicolumn{7}{|c|}{ Coefficients $^{\mathrm{a}}$} \\
\hline \multirow{2}{*}{\multicolumn{2}{|c|}{ Model }} & \multicolumn{2}{|c|}{$\begin{array}{l}\text { Unstandardized } \\
\text { Coefficients }\end{array}$} & \multirow{2}{*}{\begin{tabular}{|c|}
$\begin{array}{c}\text { Standard } \\
\text { ized } \\
\text { Coefficie } \\
\text { nts }\end{array}$ \\
Beta
\end{tabular}} & \multirow[b]{2}{*}{$\mathrm{t}$} & \multirow[b]{2}{*}{ Sig. } \\
\hline & & B & $\begin{array}{l}\text { Std. } \\
\text { Error }\end{array}$ & & & \\
\hline \multirow[t]{2}{*}{1} & (Constant) & 49.544 & 4.762 & & 10.405 & .000 \\
\hline & $\begin{array}{c}\text { media } \\
\text { pembelajaran } \\
\text { alat permainan } \\
\text { edukatif ( } \mathrm{APE} \text { ) }\end{array}$ & 961 & .106 & 826 & 950 & .982 \\
\hline \multicolumn{5}{|c|}{$\begin{array}{l}\text { a. Dependent Variable: peningkatan } \\
\text { perkembangan kognitif anak usia dini }\end{array}$} & & \\
\hline
\end{tabular}

Output ( Coeficients ) pada table coefisient pada kolom B constanta ( a ) adalah 49,544, sedangkan nilai trust ( b ) adalah 0,961, sehingga persamaan regresinya dapat ditulis:

$$
\mathrm{Y}=\mathrm{a}+\mathrm{bx}
$$

Atau 49,544 + 0,961 x koefisien b dinamakan arah regresi dan menyatukan perubahan rata - rata variabel y untuk setiap perubahan ini merupakan pertambahan bila $b$ bertanda positif dan penurunan bila $b$ bertanda negatife.Sehingga dari persamaan dapat diterjemahkan:

1. Konstanta sebesar 49,544 menyatakan bahwa jika tidak ada nilai trust maka nilai partisipan sebesar 49,544\%.

2. Koefisien regresi $X$ sebesar ( 0,961) menyatakan bahwa nilai partisipan berkurang $961 \%$. Uji regresi terdapat pada hipotensis:

1. Ho = tidak ada pengaruh yang nyata ( signifikan ) variable trust ( $\mathrm{x}$ ) terhadap variable ( y )

2. $\mathrm{H}_{1}=$ ada pengaruh yang nyata ( signifikan ) variable trust $(\mathrm{x})$ terhadap variable $(\mathrm{Y})$

Dari output di atas dapat di ketahui nilai $\mathrm{t}$ hitung $=10,405$ dengan nilai signifikan 0,682 > 0,05, maka Ho ditolak dan H1 diterima yang berarti ada pengaruhnya yang nyata ( signifikan ) variable trust $(\mathrm{X})$ terhadap variable partisipan ( Y ).

\section{E. KESIMPULAN DAN SARAN \\ KESIMPULAN}

Berdasarkan hasil penelitian dan pembahasan yang telah diuraikan pada bab sebelumnya, dapat disimpulkan sebagai berikut. Setelah menggunakan uji regression dalam SPSS kelompok A PAUD Tunas Bangsa Podomoro dalam judul penelitian pengaruh penggunaan media pembelajaran alat permainan edukatif APE terhadap peningkatan perkembangan kognitif anak usia dini tahun ajaran 2019/2020 kecamatan pringsewu kabupaten pringsewu dapat dilihat dari adanya pengaruh media pembelajara APE terhadap perkembangan anak. Dari output tersebut diperoleh koefisien determinasi ( R2) sebesar 0,051 yang mengandung pengertian bahwa pengaruh variable bebas ( Trust ) terhadap variable terikat ( partisipasi ) adalah 51\%. Dari output di atas dapat di ketahui nilai t hitung $=10,405$ dengan nilai signifikan 0,382 >0,05, maka Ho ditolak dan H1 diterima yang berarti ada pengaruhnya yang nyata ( signifikan ) variable trust ( $\mathrm{x}$ ) terhadap variable partisipan ( $\mathrm{Y}$ ).

\section{SARAN}

Berdasarkan hasil penelitian di atas maka peneliti memberikan saran berikut :

1. Kepada kepala sekolah

Diharapkan untuk kepala sekolah supaya menyediakan lebih banyak lagi alat permainan edukatif (APE) guna untuk meningkatkan perkembangan kognitif anak .

2. Kepada guru

Diharapkan guru dapat meningkatkan perkembangan kognitif anak melalui penggunaan media pembelajaran alat permainan edukatif APE untuk meningkatkan perkembangan kognitif anak.

\section{DAFTAR PUSTAKA}

Aisyah Gredler, Margaret E. 2011. Learning and Instruction Teori dan aplikasi. Kencana Perdana Media Group : Jakarta

Baharuddin,Wahyuni 2017.Teori belajar dan pembelajararan.Ar-RuzzMedia: Yoggyakarta

Deny, Siren 2013. Jurnal Pendidika Dasar. Universitas Pendidikan Ganesa: Denpasar

Jahja, Yudrik. 2011. Psikologi Perkembangan. Kencana:Jakarta

Khatimah, Husnul. 2018. Meningkatkan Kemampuan Kognitif Anak Melalui Media Puzzle Pada Kelompok B Tk Tunas Harapan. Jurnal Early Childhood Education Indonesian Journal Pedagogi. 
Monks F.J., Knoers \& Hadintono Siti R.2006.

Psikologi Perkembangan Pengantar dalam

Berbagai Bagiannya. Gajah Mada

UniversityPress: Yogyakarta

Myrnawati, C.H. 2012. Jurnal Pendidikan Anak Usia Dini Volume 6 No. 2. Program Studi Pendidikan Anak Usia Dini Program Program Pascasarjana Universitas Negeri Jakarta:

Jakarta

Siregar, Syofian. 2013. Metode Penelitian Kuantitatif.

Kencana: Jakarta

Soebachman, Agustina. 2012. Permainan Asyik Bikin Anak Pintar. IN Azna Books: Yogyakarta.

Sriastuti, Lasmawan, Marhaeni. 2014. Peningkatan

Minat Belajar Dan Kemampuan Dasar Kognitif

Melalui Penggunaan Media Puzzle Pada Anak

Kelompok B Tk Dharma Kumara Pedungan 